Article

\title{
Thermophilic Anaerobic Digestion: Enhanced and Sustainable Methane Production from Co-Digestion of Food and Lignocellulosic Wastes
}

\author{
Aditi David ${ }^{1}$, Tanvi Govil ${ }^{1}$, Abhilash Kumar Tripathi ${ }^{1}$, Julie McGeary ${ }^{2}$, Kylie Farrar ${ }^{3}$ \\ and Rajesh Kumar Sani 1,4,* (D) \\ 1 Department of Chemical and Biological Engineering, South Dakota School of Mines and Technology, \\ Rapid City, SD 57701, USA; aditi.david@mines.sdsmt.edu (A.D.); tanvi.govil@mines.sdsmt.edu (T.G.); \\ abhilashkumar.tripathi@mines.sdsmt.edu (A.K.T.) \\ 2 Biology Teacher, Central High School, Rapid City, SD 57701, USA; julie.mcgeary@k12.sd.us \\ 3 Science Teacher, Russell Middle School, Colorado Springs, CO 80918, USA; kyliefarrar23@gmail.com \\ 4 BuG ReMeDEE Consortium, South Dakota School of Mines and Technology, Rapid City, SD 57701, USA \\ * Correspondence: rajesh.sani@sdsmt.edu; Tel.: +1-605-394-1240
}

Received: 6 July 2018; Accepted: 4 August 2018; Published: 8 August 2018

\begin{abstract}
This article aims to study the codigestion of food waste (FW) and three different lignocellulosic wastes (LW) (Corn stover (CS), Prairie cordgrass (PCG), and Unbleached paper (UBP)) for thermophilic anaerobic digestion to overcome the limitations of digesting food waste alone (volatile fatty acids accumulation and low C:N ratio). Using an enriched thermophilic methanogenic consortium, all the food and lignocellulosic waste mixtures showed positive synergistic effects of codigestion. After 30 days of incubation at $60{ }^{\circ} \mathrm{C}(100 \mathrm{rpm})$, the highest methane yield of $305.45 \mathrm{~L} \cdot \mathrm{kg}^{-1}$ volatile solids (VS) was achieved with a combination of FW-PCG-CS followed by 279.31 L $\cdot \mathrm{kg}^{-1} \mathrm{VS}$ with a mixture of FW-PCG. The corresponding volatile solids reduction for these two co-digestion mixtures was $68 \%$ and $58 \%$, respectively. This study demonstrated a reduced hydraulic retention time for methane production using FW and LW.
\end{abstract}

Keywords: thermophilic anaerobic digestion; corn stover; prairie cord grass; unbleached paper; digester performance; process stability; synergistic effects; microbial community; Methanothermobacter

\section{Introduction}

Anaerobic digestion for the production of biogas is an environmentally friendly multi-step process employing complex consortia of microorganisms. These consortia comprise various facultative or obligate anaerobic microbial groups which work synergistically and convert complex organic substrates into biogas. Biogas with $60-70 \%$ of its component being methane is a combustible renewable energy that can be used as an alternative energy source to replace fossil fuels, either by direct combustion to generate heat and electricity, or through upgradation to be used as vehicle fuel and injection into the gas grid [1-4]. After the on-site demand of the produced biogas is met, the remaining biogas is usually stored as compressed natural gas (CNG) or liquefied biomethane (LBM) for future use. While the biogas industry in Europe is well established, with more than 10,000 biogas producing Anaerobic digestion (AD) plants in operation, in the United States, the biogas industry is still growing. According to the American Biogas Council, 1241 wastewater treatment plants and 236 farms have functional Biogas plants [5]. Currently, the feedstocks used for biogas production in these anaerobic digesters are limited, and therefore it is important to explore new substrates to meet the growing energy needs.

Food waste (FW) is an attractive substrate for AD because of its low total solids (TS) and high content of soluble organics which make it readily biodegradable. Additionally, FW offers 
low-cost alternatives for methane production and is abundantly available. The Food and Agriculture Organization of the United Nations reports a wastage of 1.3 billion tons of food per year. Therefore, using FW to produce methane appears to be an ideal way to strengthen the world's energy security while addressing waste management and nutrient recycling [6]. The AD of FWs, however, depends on the delicate balance between the acidification process and methanogenesis [7]. Many studies have attributed the low stability and efficiency of individual FW fermentation to the low $\mathrm{C} / \mathrm{N}$ ratio, ammonia accumulation, and the readily biodegradable organic fraction that causes acidification [8]. If the acidification process is rapid, the accumulation of volatile fatty acids (VFAs) occurs, causing an abrupt fall in $\mathrm{pH}$, which stresses and inhibits the methanogenic archaea $[9,10]$. The reactor acidification through reactor overload is one of the most common reasons for process deterioration in anaerobic digesters [11]. Therefore, the codigestion of FW with other organic wastes, such as municipal wastewater treatment plant sludge, animal manure, and agricultural biomass, has become popular, as it provides the ability to alter the carbon and nitrogen ratios which prevent accumulation of intermediate inhibitory products $\left(\mathrm{NH}_{4}{ }^{+}\right.$and VFAs) [12-14] and increase the methane yield, as well as improve the utilization efficiency [8]. The use of co-substrates for AD has shown to produce higher biogas yields due to positive synergisms established in the digestion medium and the supply of missing nutrients by the co-substrates $[15,16]$. Mixing organic substrates often results in the formation of a codigestion mixture with a $\mathrm{C} / \mathrm{N}$ ratio included in the optimal range of $20-30 \%$ as reported in the literature [16-18]. The additional benefits of the codigestion process are (1) the dilution of the potential toxic compounds present in any of the co-substrates involved; (2) the adjustment of the moisture content and $\mathrm{pH}$; (3) supply of the necessary buffer capacity to the mixture; (4) the increase of the biodegradable material content; and (5) the widening the range of bacterial strains taking part in the process [17].

Like food waste, lignocellulosic wastes (LW), which include agricultural residues (corn stover, rice straw), herbaceous crops (switchgrass, prairie cordgrass) and waste paper, are extensively available low-cost substrates. Lignocellulosic wastes are in fact the most abundant renewable organics, reaching, annually, over 150 billion tons in the form of plant biomass [19]. Due to their chemical composition based on sugars and other compounds of interest, they could be utilized to produce several value-added products, such as ethanol, biogas, food additives, organic acids, enzymes, and others [20-23]. Therefore, besides the environmental problems caused by their accumulation, the non-utilization of these materials constitutes a loss of potentially valuable sources [24]. Previous studies report that the methane generation potential is expected to be much higher if lignocellulosic biomass resources are used. It is estimated that 4.2 trillion cubic feet per year (about 4,318 trillion British thermal units [25]) LW are available, the biogasification of which can displace about $46 \%$ of current natural gas consumption in the electric power sector and the entire natural gas consumption in the transportation sector [26]. Moreover, being a second-generation feedstock for biofuel, the use of lignocellulosic residues does not compete for arable land [27,28]. Thus, utilizing LW in the AD process is a promising option. Still, the AD of LW alone has several limitations, such as the high C:N ratio creating nitrogen deficiency, the risk of producing inhibitors (e.g., furfural and hydroxymethylfurfural), a less digestible biomass, a high heat demand [29,30], and long digestion time due to their low cellulose, hemicellulose, and lignin conversion rates [8].

Performing anaerobic codigestion of FW with LW can overcome the limitations of their respective mono-digestions. Previous studies have also demonstrated the role of codigestion of FW and LW in the adjustment of $\mathrm{C}: \mathrm{N}$ ratio [31], in the reduction of the start-up time and volatile fatty acid (VFA) accumulation [32], and in the enhancement of methane yield. Yong et al., 2015 examined the potential of co-digestion of food waste and straw at $35{ }^{\circ} \mathrm{C}$. The study showed increased methane yield reaching $0.392 \mathrm{~m}^{3} \cdot \mathrm{kg}^{-1} \mathrm{VS}$ at an optimal mixing ratio of 5:1 (FW: straw), which marked a 39.5\% and $149.7 \%$ increase in methane yield compared with individual digestion results of food waste and straw, respectively [8]. In another study, Jabeen et al., 2015, codigested FW with rice husk in a pilot-scale mesophilic $\left(37^{\circ} \mathrm{C}\right)$ anaerobic reactor. They obtained a daily biogas production of $196 \mathrm{~L} \cdot \mathrm{d}^{-1}$, at an organic loading rate of $6 \mathrm{~kg} \mathrm{VS} \cdot \mathrm{m}^{-3} \cdot \mathrm{d}^{-1}$, which decreased to $136 \mathrm{~L} \cdot \mathrm{d}^{-1}$ at a loading rate of 
$9 \mathrm{~kg} \mathrm{VS} / \mathrm{m}^{3} / \mathrm{d}$. They attributed the decrease in biogas production, reactor stability, and volatile solids removal efficiency to the increase in organic loading rate [33]. These effects of high organic loading rate are more profound in mesophilic anaerobic reactors as compared to thermophilic reactors.

In all the studies mentioned above, the anaerobic co-digestion of FW and LW improved process performance and increased biogas production. However, a major disadvantage of using LW is the recalcitrant nature of their cell wall. The intricate composition of lignocellulosic materials, where cellulose fiber is tightly linked to hemicellulose and lignin, hinders their biodegradability and thus limits their use as co-substrates for $\mathrm{AD}$. The recalcitrant nature of the $\mathrm{LW}$ necessitates the inclusion of the pretreatment step (physical, chemical or biological) for their efficient conversion into biofuels [34]. The use of thermophilic digesters can eliminate the use of costly and sometimes hazardous pretreatment steps. Thermophilic anaerobic digestion (TAD) allows for the better degradation of LW by increasing the microbial hydrolysis rate which is considered the slowest as well as rate limiting step [35]. Besides aiding methanogenesis through increased hydrolysis rate, TAD also decreases the level of pathogens. This reduces the potential health hazards for the biogas plant operators as well as ensures safe disposal of the digestate after process completion [36].

Most of the studies to date on the codigestion of FW and LW have been conducted under mesophilic conditions [31,33,37-39] which require higher hydraulic retention times (HRTs) and lower organic loading rates. Here, however, we attempt to assess the methane production from codigestion of FW and LW under thermophilic conditions. The objectives of this study were to (1) evaluate the methane potential and biodegradability of FW, corn stover (CS), prairie cordgrass (PCG), and unbleached paper (UBP) at $60{ }^{\circ} \mathrm{C}$ and (2) describe the trends of methane yield, process stability, and digester performance, when these are codigested using a pre-acclimatized thermophilic methanogenic consortium. In South Dakota, PCG is abundant and can offer local alternatives to corn for the production of biofuels. This study is the first attempt at investigating the co-digestion of FW with PCG under thermophilic conditions $\left(60^{\circ} \mathrm{C}\right)$. The results of this study could provide baseline data for the adoption of Thermophilic Anaerobic Digestor (TAD) using readily available PCG as feedstocks for biogas generation.

\section{Materials and Methods}

\subsection{Feedstock and Inoculum}

The FW and three different types of LW-CS, PCG, and UBP-were used as feedstocks for TAD. CS and PCG were kindly provided by Dr. K. Muthukumarappan from South Dakota State University, Brookings, SD. The FW and UBP were collected from the cafeteria at the South Dakota School of Mines and Technology and stored at $4{ }^{\circ} \mathrm{C}$. LW were reduced in size using a cutting mill and sieved through sieve between 15 and $10 \mathrm{~mm}$ pores (SM 200, Rectch GmbH, Haan, Germany). The particle size of the FW was also reduced by crushing it in an electrical kitchen blender, and the resultant FW slurry was sieved to remove coarse particles larger than $15 \mathrm{~mm}$. The effect of shredding paper had been tested previously and did not influence the AD performance [40], so the UBP was hand cut. Inoculum used in this study was effluent procured from an anaerobic digester at the Waste Water Reclamation Plant, Rapid City, SD which was enriched in our lab. The enrichment details are included in our previous report [41]. This enriched thermophilic methanogenic consortia (called TMC) was used as the inoculum for this study and stored in an air-tight container at $-20^{\circ} \mathrm{C}$. The characteristics of substrates and inocula are presented in Table 1. Each data point presented was the average of triplicate measurements of the same feedstock.

\subsection{Experimental setup for Batch Tests}

Batch tests were conducted in $500 \mathrm{~mL}$ serum bottles with a working volume of $200 \mathrm{~mL}$ containing $180 \mathrm{~mL}$ of anaerobic culture medium and $20 \mathrm{~mL}(10 \%, v / v)$ TMC. The composition of the anaerobic culture medium is given in Table 1. To analyze the feasibility of the individual FW and LW for 
anaerobic digestion, different organic loadings (1\%, $2 \%, 5 \%$, and $10 \% w / v$ VS) of these samples were first tested, which constituted 16 mono-digestion tests (Table 2). Based on this, seven FW samples ( $1 \mathrm{~g}$ VS each) were separately mixed with CS, PCG, or UBP for the anaerobic co-digestion study in mixing ratios as given in Table 3 . The substrate-free serum bottles containing inoculum, and the media served as controls. The experiments were repeated three times under the same conditions using the same co-digestion mixing ratios. The average $\mathrm{pH}$ of digestion mixtures $\mathrm{T} 1, \mathrm{~T} 2, \mathrm{~T} 3, \mathrm{~T} 4, \mathrm{~T} 5, \mathrm{~T} 6$, and $\mathrm{T} 7$ after mixing with inoculum were 7.1, 7.1, 7.2, 7.1, 7.2, 7.3, and 7.3, respectively.

The substrates (according to Tables 1 and 2), media and 10\% $(v / v)$ inoculum were added in the serum bottles to make a total working volume of $200 \mathrm{~mL}$. These digester bottles were capped with butyl rubber stoppers, crimped with aluminum caps, and nitrogen gas was purged into them for $20 \mathrm{~min}$ to simulate anaerobic conditions. The bottles were then incubated at $60{ }^{\circ} \mathrm{C}(100 \mathrm{rpm})$ for up to 30 days. Methane production was monitored at different time intervals, and the methane yield was reported as $\mathrm{mL} \mathrm{CH}_{4}$ per gram of Volatile solids $\left(\mathrm{mL} \mathrm{CH}_{4} / \mathrm{g} \mathrm{VS}\right)$.

Table 1. The composition of the anaerobic culture medium.

\begin{tabular}{cc}
\hline Components & Composition $(\mathrm{g} / \mathrm{L})$ \\
\hline $\mathrm{K}_{2} \mathrm{HPO}_{4}$ & 0.30 \\
$\mathrm{KH}_{2} \mathrm{PO}_{4}$ & 0.30 \\
$\mathrm{NaCl}_{\mathrm{CaCl}}$ & 0.10 \\
$\mathrm{NH}_{4} \mathrm{Cl}$ & 0.05 \\
$\mathrm{MgCl} \cdot 6 \mathrm{H}_{2} \mathrm{O}$ & 1.00 \\
$\mathrm{KCl}$ & 0.50 \\
$\mathrm{Cysteine} \cdot \mathrm{HCl}$ & 0.30 \\
Yeast extract & 0.50 \\
$\mathrm{Na}_{2} \mathrm{~S} \cdot 9 \mathrm{H}_{2} \mathrm{O}$ & 0.05 \\
$\mathrm{NaHCO}_{3}$ & 0.003 \\
Nitsch trace element & $20 \mathrm{mM}$ \\
\hline
\end{tabular}

Table 2. The feedstock composition in the batch tests with individual wastes.

\begin{tabular}{cccccccccccccccc}
\hline $\begin{array}{c}\text { Individual Substrate } \\
\text { Type }\end{array}$ & \multicolumn{3}{c}{$\begin{array}{c}\text { Food Waste } \\
\text { (FW) }\end{array}$} & \multicolumn{3}{c}{$\begin{array}{c}\text { Corn Stover } \\
\text { (CS) }\end{array}$} & \multicolumn{3}{c}{$\begin{array}{c}\text { Prairie Cordgrass } \\
\text { (PCG) }\end{array}$} & \multicolumn{3}{c}{$\begin{array}{c}\text { Unbleached Paper } \\
\text { (UBP) }\end{array}$} \\
\hline $\begin{array}{c}\text { Organic Loading (\%) s } \\
\begin{array}{c}\text { Composition } \\
\text { (g VS) }\end{array}\end{array}$ & $2.5 \%$ & $5 \%$ & $10 \%$ & $1 \%$ & $2.5 \%$ & $5 \%$ & $10 \%$ & $1 \%$ & $2.5 \%$ & $5 \%$ & $10 \%$ & $1 \%$ & $2.5 \%$ & $5 \%$ & $10 \%$ \\
& 5 & 10 & 20 & 2 & 5 & 10 & 20 & 2 & 5 & 10 & 20 & 2 & 5 & 10 & 20 \\
\hline
\end{tabular}

Table 3. The feedstock composition in batch tests $\left(60^{\circ} \mathrm{C}\right)$ with codigestion mixtures.

\begin{tabular}{cccccccc}
\hline Test Bottles & T1 & T2 & T3 & T4 & T5 & T6 & T7 \\
\hline Composition & FW & FW + CS & FW + PCG & FW + UBP & FW + PCG + CS & FW + PCG + UBP & FW + UBP + CS \\
\hline FW (g VS) & 2.5 & 2.5 & 2.5 & 2.5 & 2.5 & 2.5 & 2.5 \\
CS (g VS) & - & 1.5 & - & - & 0.75 & - & 0.75 \\
PCG (g VS) & - & - & 1.5 & - & 0.75 & 0.75 & - \\
UBP (g VS) & - & - & - & 1.5 & - & 0.75 & 0.75 \\
Mixing Ratio & - & $5: 3$ & $5: 3$ & $5: 3$ & $5: 1.5: 1.5$ & $5: 1.5: 1.5$ & $5: 1.5: 1.5$ \\
C:N & $19: 1$ & 23.9 & 25.6 & 28.2 & 24.4 & 26.8 & 25.6 \\
\hline
\end{tabular}

(Note: FW = Food wastes; CS = Corn stover; PCG = Prairie cordgrass; UBP = Unbleached paper).

\subsection{Analytical Methods}

Total Solids (TS) and Volatile solids (VS) of the inoculum and feedstock were analyzed according to APHA Standard Methods [42]. The cellulose, hemicellulose, and lignin content were determined according to standard NREL analytical procedures [43]. The product gas was sampled using a $100 \mu \mathrm{L}$ gas-tight glass syringe (Hamilton Company, Reno, NV, USA), and measured using gas chromatography (Agilent Technologies 7890A) equipped with a thermal conductivity detector at $200^{\circ} \mathrm{C}$ and a Supelco 
Porapak Q stainless steel packed column $(6 \mathrm{ft} \times 1 / 8 \mathrm{in})$. Nitrogen was the carrier gas at a rate of $10 \mathrm{~mL} / \mathrm{min}$. The conditions for $\mathrm{CH}_{4}$ analysis were as follows: injector temperature: $70^{\circ} \mathrm{C}$; detector temperature: $100{ }^{\circ} \mathrm{C}$; and oven temperature: $1 \mathrm{~min}$ at $35^{\circ} \mathrm{C}$, followed by a $5^{\circ} \mathrm{C} / \mathrm{min}$ ramp to $50^{\circ} \mathrm{C}$ with a hold time of $2 \mathrm{~min}$ (total run time $4.5 \mathrm{~min}$ ). The VFAs (acetic acid, propionic, and butyric acid) were measured using an Aminex HPX-87 H column with $0.005 \mathrm{~N}$ sulfuric acid as the mobile phase. Liquid samples were sent to Atlantic Microlab, Norcross, GA for elemental analysis.

Methane yield (mL/g VS) was calculated as the volume of methane as produced per $\mathrm{g}$ of VS feedstock loaded into the digester bottles initially and corrected by subtracting the methane yield obtained from the control bottle [44]. VS represents the organic portion of the material solids that can be digested, while the remainder of the solids is considered as fixed. The 'fixed' solids are non-biodegradable [45]. The $\mathrm{pH}$ value of each mixture before and after the digestion process was measured with an Oakton pH 700 meter. Process stability was assessed in terms of final $\mathrm{pH}$ and VFA accumulation, and performance was measured in terms of methane production and VS removal efficiencies. The carbon to nitrogen ratio was calculated using the following equation [37]:

$$
\mathrm{C}: \mathrm{N}=\frac{(\mathrm{VS} * \mathrm{TOC})_{F W}+(\mathrm{VS} * \mathrm{TOC})_{L W}}{(\mathrm{VS} * \mathrm{TN})_{F W}+(\mathrm{VS} * \mathrm{TN})_{L W}}
$$

where $\mathrm{TOC}=$ the total organic carbon $(\% \mathrm{VS})$ and $\mathrm{TN}=$ total nitrogen $(\% \mathrm{VS})$.

\subsection{Statistical Analysis}

The batch tests were conducted in triplicates, and each data point was the average of triplicate readings for all the chemical analysis and measurements. The statistical significance of the results was analyzed by Analysis of Variance (Two-way ANOVA) with a 95\% level of confidence $(p=0.05)$ [46]. Statistical analysis was done using GraphPad Prism version 7.04 (GraphPad Software, San Diego, CA, USA). The results of the analysis are given in the supplementary files.

\section{Results and Discussion}

\subsection{Feedstock and Inoculum Characteristics}

The results of the feedstock characterization are shown in Table 4. FW had a moisture content of $84.8 \%$ and a VS/TS ratio of $90.8 \%$. These results comply with previous reports in the literature where the moisture content and VS/TS ratio of FW was $69-93 \%$ and $85-95 \%$, respectively [47]. FW containing a high amount of digestible organic matter is suitable for anaerobic microbial growth and attaining high methane yield. However, elemental analysis showed that FW had a C:N ratio of 13:1, which was too low to maintain nutrient balance in the anaerobic digester. TS and VS contents of the three LW (CS, PCG, UBP) were higher than that of FW, and their VS/TS ratios were between $85 \%$ to $95 \%$ making them suitable feedstocks for TAD (Table 1). The C:N ratio was found to be the highest for UBP (124:1), followed by CS (55:1) and PCG (41:1), which was higher than the optimum range required (20-30:1) [48]. The cellulose content was the highest in UBP (84.5\%) and lowest in PCG (30.3\%). CS had the highest hemicellulose content among the tested feedstocks and PCG had the highest lignin content. UBP had the lowest hemicellulose and lignin content.

The inoculum (TMC) used in this study was enriched through sub-culturing techniques [41]. Briefly, $10 \%(v / v)$ effluent from the wastewater reclamation plant was inoculated in $200 \mathrm{~mL}$ of anaerobic medium (Table 1) in $500 \mathrm{~mL}$ serum bottles. One-gram VS of mixed wastes (containing equal amounts of FW, CS, PCG, and UBP) was used as the substrate and the bottles were incubated at $60^{\circ} \mathrm{C}$ and $100 \mathrm{rpm}$. When methane production reached a stable level, $10 \%(v / v)$ of the actively growing anaerobic culture was transferred into fresh media $(200 \mathrm{~mL})$ containing another $1 \mathrm{~g}$ of mixed waste. After 10 serial transfers, a methanogenic consortium growing at $60^{\circ} \mathrm{C}$ was obtained that produced methane using FW, CS, PCG, and UBP as a carbon and energy source. The enriched TMC had a VS content, TS content, and C:N ratio of $6.1 \%, 8.3 \%$, and 2.7 , respectively. During optimization, a $\mathrm{pH}$ of $7.5,2-3 \%(w / v)$ 
substrate loading, and $10 \%(v / v)$ inoculum density had a profound effect on consortium growth and subsequent methane production. The microbial community analysis of the inoculum highlighted the role of the bacterial orders-Clostridiales, Bacillales, Bacteroidales, and Thermoanaerobacteriales-in the anaerobic degradation of the complex organic polymers present in FW and LW. As expected, the hydrogenotrophic pathway was found to be the dominant pathway of methanogenesis where Methanothermobacter were the predominant archaea in TAD (Supplementary Figure S2A-D).

Table 4. The characteristics of inoculum and feedstock ${ }^{\mathrm{a}}$.

\begin{tabular}{|c|c|c|c|c|c|}
\hline Parameters & Inoculum & FW & CS & PCG & UBP \\
\hline TS $(\% w / w)$ & 8.3 & 15.2 & 94.3 & 87.6 & 96.2 \\
\hline $\mathrm{VS}(\% w / w)^{\mathrm{b}}$ & 6.1 & 13.8 & 92.6 & 76.9 & 84.7 \\
\hline $\operatorname{Ash}(\% w / w)^{b}$ & 93.9 & 86.2 & 7.4 & 23.1 & 15.3 \\
\hline VS/TS (\%) & 37.2 & 90.8 & 98.2 & 87.8 & 88.0 \\
\hline $\mathrm{C}: \mathrm{N}^{\mathrm{c}}$ & 2.7 & $13: 1$ & $55: 1$ & $41: 1$ & $124: 1$ \\
\hline VFA/alkalinity & 1.3 & ND & ND & ND & ND \\
\hline Lignin $(\%)^{b}$ & ND & ND & 13.5 & 22.9 & 2.1 \\
\hline Cellulose $(\%)^{b}$ & ND & ND & 38.2 & 30.3 & 84.5 \\
\hline Hemicellulose (\%) $\mathrm{b}$ & ND & ND & 32.4 & 25.7 & 11.2 \\
\hline
\end{tabular}

\subsection{Thermophilic Anaerobic Digestion of Individual Waste Substrates}

Cumulative methane production for organic loadings of $1,2.5,5$, and $10 \%(w / v$ VS) of FW is shown in Figure 1. The highest methane yield of $321.5 \mathrm{~L} \cdot \mathrm{kg}^{-1} \mathrm{VS}$ was obtained with an organic loading of $1 \% \mathrm{FW}$. The further increase of organic loading resulted in a significant decrease in methane production $(p<0.05)$, indicating inhibition of methanogenesis. This is due to the rapid rise in the concentration of VFAs with increasing organic load, causing an abrupt fall in $\mathrm{pH}(<5.3)$ and the consequent acidification of the anaerobic system (Figure 2). Previous studies have also reported a similar trend, in which the accumulation of superfluous VFAs was found to be inhibitory towards methanogens, thus causing a drop in their activity $[49,50]$. The instability of the FW digesting system can also be attributed to the low $\mathrm{C}: \mathrm{N}$ ratio of FW. A low $\mathrm{C}: \mathrm{N}$ ratio causes ammonia accumulation, reduced substrate degradation, and even an inhibition of methanogenesis [8].

The codigestion of FW with lignocellulosic biomass has shown to solve the problem by bringing in an opportunity to balance the nutrients content $[15,51]$. However, the complex structures of lignin and other cell wall polysaccharides make lignocellulosic waste materials hard to biodegrade and to be used by anaerobic microorganisms, leading to a lower biogas production. Therefore, to assess the biodegradability of LW by the anaerobic consortia used in this study, CS, PCG, and UBP were digested individually at different organic loading rates $(1,2.5,5$, and $10 \% ; w / v$ VS). Figure 1 presents the results of the mono-digestion study. The methane yield and solid content for all the substrates tested showed an inverse relationship where $1 \% w / v$ substrate gave the highest methane yield. Cumulative methane yields obtained with $1 \% \mathrm{LW}$ were $236.14 \mathrm{~L} \cdot \mathrm{kg}^{-1} \mathrm{VS}$ for UBP followed by CS (111.05 L $\cdot \mathrm{kg}^{-1} \mathrm{VS}$ ) and PCG $\left(94.87 \mathrm{~L} \cdot \mathrm{kg}^{-1} \mathrm{VS}\right)$. The methane yields obtained in this study were comparable with values (80 to $530 \mathrm{~L} \cdot \mathrm{kg}^{-1} \mathrm{VS}$ ) reported by others for the same or similar agricultural and energy crops [39,52-54]. Substrate concentrations of more than $1 \% \mathrm{w} / \mathrm{v}$ showed a significant decrease in methane production $(p<0.05)$. Nevertheless, these results indicated that the TMC can efficiently degrade LW anaerobically. 


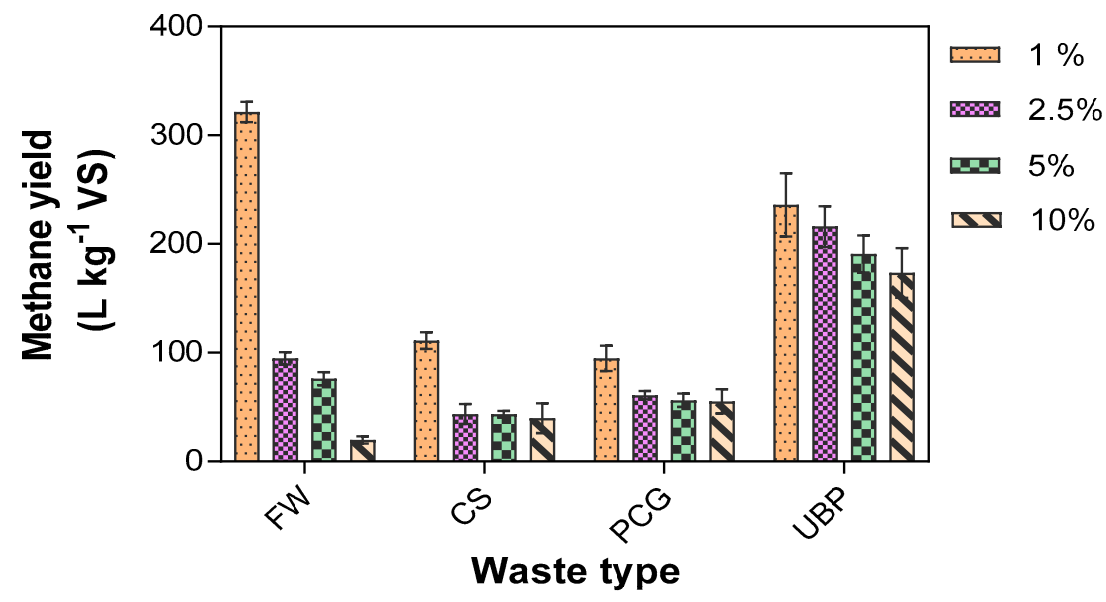

Figure 1. The methane yield from different organic loadings of food waste (FW), corn stover (CS), prairie cord grass (PCG), and unbleached paper (UBP). The data represented are the average values of the triplicate bottles. The error bars represent the standard deviation.

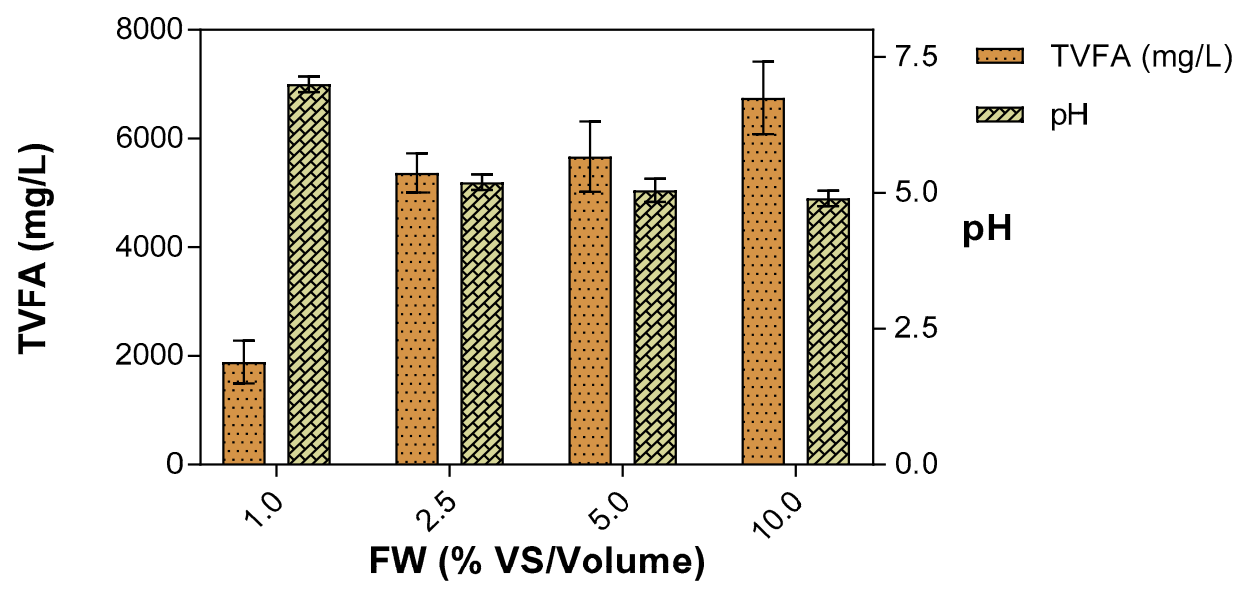

Figure 2. The Total Volatile Fatty Acid (TVFA) concentration and $\mathrm{pH}$ at the end of batch tests (the data represented are the average values of the triplicate bottles. The error bars represent the standard deviation).

\subsection{Effect of Codigestion on Methane Yield and Digester Performance}

High organic loading rates are desirable to reduce the digester volume and minimize capital losses, however, increased organic loading rates often result in VFA accumulation, nutrient imbalance, and sometimes the direct inhibition of methanogenesis, leading to complete digester failure [55-57]. Codigestion experiments were carried out with an organic loading of $2.5 \% \mathrm{FW}$ to analyze the efficacy of codigestion in overcoming the limitations of high organic loadings observed in mono-digestion experiments. In the first set of tests, FWs $(2.5 \%$ VS) were codigested with LW individually in three separate serum bottle digesters (T2, T3, and T4) where the concentration of CS, PCG, and UBP was $1.5 \% w / v$ (VS basis). As shown in Figure 3a, methane volume produced in these co-digestion studies with two waste mixtures was considerably higher than that obtained from the mono-digestion of FW $(p<0.05)$. This demonstrates positive synergistic effects among codigested wastes. The highest methane yield of $279.31 \mathrm{~L} \cdot \mathrm{kg}^{-1}$ was observed in T3 (FW + PCG), followed by $251.90 \mathrm{~L} \cdot \mathrm{kg}^{-1}$ in T2 $(\mathrm{FW}+\mathrm{CS})$ and $177.48 \mathrm{~L} \cdot \mathrm{kg}^{-1}$ in T4 (FW + UBP). Because a higher reduction in VS is indicative of better digester performance, a direct correlation between methane production and VS reduction was observed in this study $(p<0.05)$. Digester bottles with higher VS reduction yielded higher methane. 
The highest VS reduction of $45.7 \%$ was achieved in T3 (FW + PCG) followed by $38.7 \%$ in T2 (FW + CS), and $38.3 \%$ in T4 (FW + UBP). The lowest biodegradability of the FW + UBP mixture is reflected in the mixture's lower VS removal and consequently in its lowest methane yield.

The second set of experiments where the co-digestion mixtures comprised of $2.5 \% w / v$ FW and two LW $(0.75 \% w / v$ each on VS basis) showed a similar pattern of results (Figure $3 b)$. The highest methane yield of $305.45 \mathrm{~L} \cdot \mathrm{kg}^{-1} \mathrm{VS}$ and a VS reduction of $68.5 \%$ were obtained with FW:CS:PCG (T5) mixture, while the lowest yield of $219.9 \mathrm{~L} \cdot \mathrm{kg}^{-1} \mathrm{VS}$ and a VS reduction of $49.8 \%$ was observed with FW + UBP + CS (T7) mixture. The higher methane production for some codigestion mixtures over others can be attributed to the $\mathrm{C} / \mathrm{N}$ ratio for these mixtures which were in the recommended range of 20:1 and 30:1 [18,58].

At a constant organic loading of $4 \mathrm{~g} \mathrm{VS}$, the highest methane yield among all the codigested mixtures was obtained with FW + PCG + CS (305.4 L $\left.\cdot \mathrm{kg}^{-1} \mathrm{VS}\right)$, followed by FW + PCG $\left(279.3 \mathrm{~L} \cdot \mathrm{kg}^{-1}\right.$ VS). This marked a $94 \%$ and $74 \%$ increase in methane production compared to the mono-digestion of FW. Previous studies have also shown similar results but were performed at mesophilic temperatures and had higher hydraulic retention times ( $>30$ days) in comparison to our study (18 days). $\mathrm{Xu}$ and $\mathrm{Li}$, 2012 reported the highest methane yield of $304.4 \mathrm{~L} / \mathrm{kg}$ VS feed with a codigestion mixture containing an equal amount of corn stover and dog food, 109\% compared to methane yield from mono-digestion $\operatorname{dog}$ food, respectively [32]. In another study conducted by Brown and Li, 2013, the increased methane yields and volumetric productivities were observed with the co-digestion of food waste with yard waste. Food waste to yard waste mixture of 1:9 gave the highest volumetric productivity of $8.6 \mathrm{~L}$ methane $\mathrm{L}^{-1}$, with a $43 \% \mathrm{VS}$ reduction [31]. They attributed nutrient balance as one of the reasons for enhanced synergism during co-digestion.
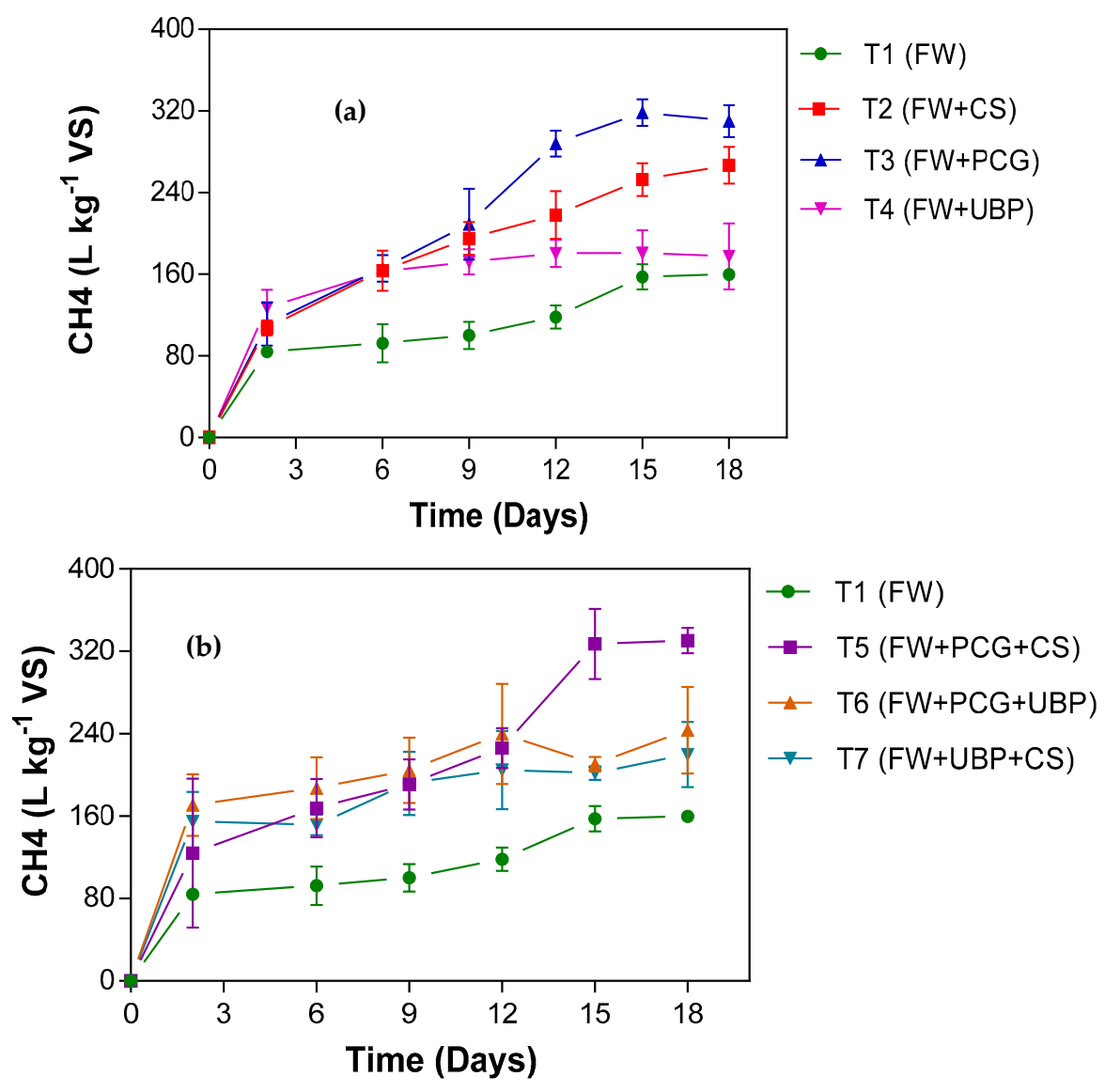

Figure 3. (a,b): methane production from the co-digestion of food and lignocellulosic waste (the data represented are the average values of triplicate bottles. The error bars represent the standard deviation). 


\subsection{Effect of Codigestion on Process Stability}

Reactor acidification due to the buildup of VFAs is one of the most common reasons for the process deterioration and instability in anaerobic digesters [48]. VFAs are naturally produced by acidogenic and acetogenic bacteria and accumulate during conditions of substrate overload in the reactor. Additionally, a high VFA concentration is usually associated with a drop in $\mathrm{pH}$ and a breakdown of the buffering capacity of the reactor [31,59]. Hence, the final $\mathrm{pH}$ values in batch tests are another measure of system stability. Maintenance of the system $\mathrm{pH}$ in the proper range (6.5 and 7.6) is required for efficient anaerobic digestion [60]. Analysis of VFA concentrations and $\mathrm{pH}$ were done at the end of the batch experiments, and the results are shown in Figure 4. While acetic acid represented major portion of the total VFAs produced, propionic acid and butyric acid were produced in lower amounts (Supplementary Figure S1). The total VFA concentration was highest for T1 (FW) followed by T4 (FW + UBP) and T7 (FW + UBP + CS) which dropped the pH below 6 in all the three digesters creating instability. This instability directly affected the methane production which is evident from the lowest methane yield observed in T1, T4, and T7 (Table 5). The results indicated that these anaerobic reactors were operating under higher loading rates. Statistical analysis also showed that VFA concentration has a significant effect on methane yield with a $p$ value of $<0.05$. The serum bottles having VFA concentrations of 1600-3300 mg/L did not show a drastic decrease in the $\mathrm{pH}$ of the system.

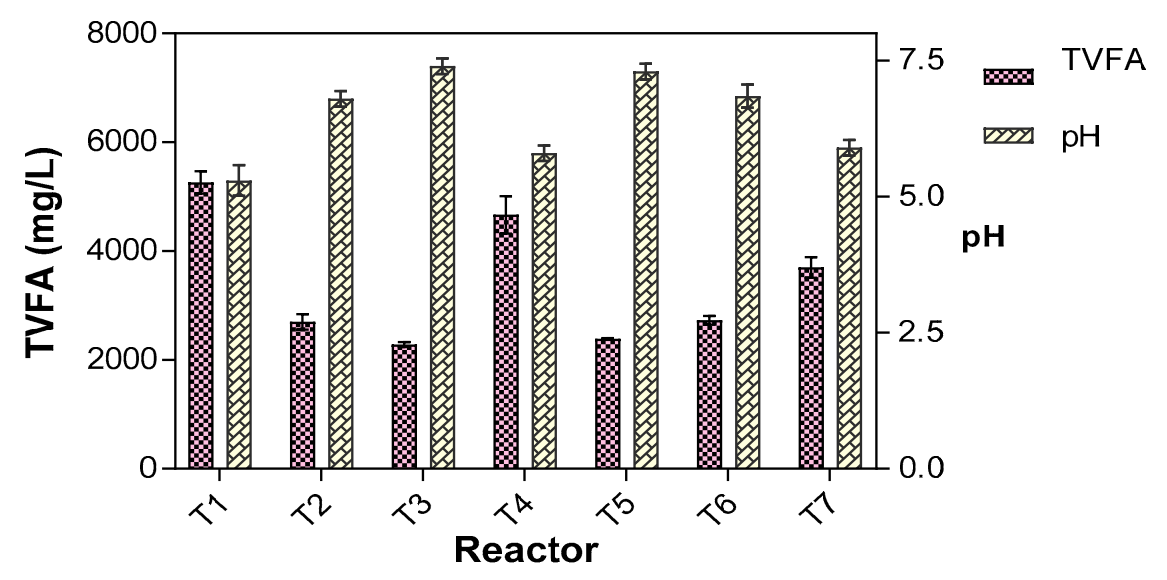

Figure 4. The Total Volatile Fatty acids (TVFA) and $\mathrm{pH}$ at the end of the codigestion tests (the data represented are the average values of triplicate bottles. The error bars represent the standard deviation).

Table 5. The effect of codigestion on digester performance.

\begin{tabular}{cccccccc}
\hline Test Bottles & T1 & T2 & T3 & T4 & T5 & T6 & T7 \\
\hline Methane yield (L·kg-1 VS) & $159.8 \pm 2.4$ & $251.9 \pm 26.6$ & $279.3 \pm 7.2$ & $177.5 \pm 16.1$ & $305.4 \pm 23.8$ & $243.6 \pm 20.9$ & $219.9 \pm 10.9$ \\
VS reduction (\%) & $44 \pm 1.4$ & $57.4 \pm 2.7$ & $58.0 \pm 0.9$ & $47.4 \pm 1.8$ & $68.5 \pm 2.2$ & $51.1 \pm 2.6$ & $49.8 \pm 1.5$ \\
Initial pH & $7.1 \pm 0.0$ & $7.1 \pm 0.2$ & $7.2 \pm 0.1$ & $7.1 \pm 0.1$ & $7.2 \pm 0.0$ & $7.3 \pm 0.3$ & $7.3 \pm 0.2$ \\
Final pH & $5.3 \pm 0.0$ & $6.8 \pm 0.1$ & $7.4 \pm 0.2$ & $5.8 \pm 0.1$ & $7.3 \pm 0.2$ & $6.8 \pm 0.1$ & $5.9 \pm 0.0$ \\
\hline
\end{tabular}

\section{Conclusions}

Biogas production using the abundant wastes as the substrate is a promising technology both in renewable energy and solid waste management sectors. FW and LW are attractive co-substrates for TAD as their complementary characteristics can overcome the limitations faced by their mono-digestion. The results suggested that codigesting FW with LW not only improved the system stability but also enhanced methane production, thus improving overall digester performance. At a constant organic loading of $4 \mathrm{~g} \mathrm{VS}$, the highest methane yield of $305.4 \mathrm{~L} \cdot \mathrm{kg}^{-1} \mathrm{VS}$ was obtained with FW + PCG + CS followed by $279.3 \mathrm{~L} \cdot \mathrm{kg}^{-1}$ VS with FW + PCG. This marked a $94 \%$ and $74 \%$ increase in methane 
production compared to the mono-digestion of FW. Since the digester bottles with these codigestion mixtures showed increased system stability as well, they will be employed for scale-up studies.

The pretreatment of the LW increases the amount of available sugars for $\mathrm{AD}$, but also increases the bioprocessing cost. As this study was conducted without employing any pretreatment, consortium development became a crucial step when the codigestion of LW was performed. The use of thermophilic temperature may increase the costs of the overall process but gives the added advantage of digesting higher organic loading of wastes at reduced hydraulic retention times. In addition, the surplus biogas produced can be used for heating purposes to maintain the reactor temperature in the thermophilic range. Nevertheless, the consortium developed in this study is significant for the co-digestion and can be used for scale-up studies. Codigestion mixtures showing the best performance and stability in this study will be used for scale-up studies to conduct the cost analysis. The present batch study can also direct further studies for setting up semi-continuous or continuous commercial scale plants for the codigestion of regionally abundant PCG with food waste and help in tackling the conditions limiting methane production from higher organic loadings.

Supplementary Materials: The following are available online at http://www.mdpi.com/1996-1073/11/8/2058/s1.

Author Contributions: A.D. conceived and designed the experiments. A.D., J.M., and K.F. performed the experiments. T.G. and A.K.T. analyzed the data, and A.D. and T.G. wrote the paper. R.K.S. contributed in the idea, experiment planning, writing, validity and interpretation of the results.

Funding: This research was supported by the US Air Force under the Biological Waste to Energy Project (Award \#FA4819-14-C-0004) and Sustainable Development-Research Experience for Teachers (SD-RET) (Award \#1711946). National Science Foundation also provided financial support in the form of the BuG ReMeDEE initiative (Award \#1736255) The authors are grateful to the Department of Chemical and Biological Engineering at the South Dakota School of Mines and Technology for the research support.

Conflicts of Interest: The authors declare no conflict of interest.

\section{Nomenclature}

$\begin{array}{ll}\text { FW } & \text { Food wastes } \\ \text { LW } & \text { Lignocellulosic wastes } \\ \text { CS } & \text { Corn Stover } \\ \text { PCG } & \text { Prairie cordgrass } \\ \text { UBP } & \text { Unbleached paper } \\ \text { AD } & \text { Anaerobic digestion } \\ \text { VFA } & \text { Volatile Fatty acids } \\ \text { C/N } & \text { Carbon to nitrogen } \\ \text { TAD } & \text { Thermophilic anaerobic digestion } \\ \text { VS } & \text { Volatile solids } \\ \text { TS } & \text { Total solids } \\ \text { TMC } & \text { Thermophilic methanogenic consortia }\end{array}$

\section{References}

1. Qian, Y.; Sun, S.; Ju, D.; Shan, X.; Lu, X. Review of the state-of-the-art of biogas combustion mechanisms and applications in internal combustion engines. Renew. Sustain. Energy Rev. 2017, 69, 50-58. [CrossRef]

2. Börjesson, P.; Mattiasson, B. Biogas as a resource-efficient vehicle fuel. Trends Biotechnol. 2008, 26, 7-13. [CrossRef] [PubMed]

3. Hengeveld, E.J;; van Gemert, W.J.T.; Bekkering, J.; Broekhuis, A.A. When does decentralized production of biogas and centralized upgrading and injection into the natural gas grid make sense? Biomass Bioenergy 2014, 67, 363-371. [CrossRef]

4. Ptak, M.; Koziołek, S.; Derlukiewicz, D.; Słupiński, M.; Mysior, M. Analysis of the Use of Biogas as Fuel for Internal Combustion Engines. In Proceedings of the 13th International Scientific Conference, Wrocław, Poland, 22-24 June 2016; Rusiński, E., Pietrusiak, D., Eds.; Springer International Publishing: Cham, Switzerland, 2017; pp. 441-450. 
5. Dahl, R. A Second Life for Scraps: Making Biogas from Food Waste. Environ. Health Perspect. 2015, 123, A180-A183. [CrossRef] [PubMed]

6. Islam, M.; Park, K.-J.; Yoon, H.-S. Methane Production Potential of Food Waste and Food Waste Mixture with Swine Manure in Anaerobic Digestion. J. Biosyst. Eng. 2012, 37, 100-105. [CrossRef]

7. Braguglia, C.M.; Gallipoli, A.; Gianico, A.; Pagliaccia, P. Anaerobic bioconversion of food waste into energy: A critical review. Bioresour. Technol. 2018, 248, 37-56. [CrossRef] [PubMed]

8. Yong, Z.; Dong, Y.; Zhang, X.; Tan, T. Anaerobic co-digestion of food waste and straw for biogas production. Renew. Energy 2015, 78, 527-530. [CrossRef]

9. Staley, B.F.; de los Reyes, F.L.; Barlaz, M.A. Effect of Spatial Differences in Microbial Activity, pH, and Substrate Levels on Methanogenesis Initiation in Refuse. Appl. Environ. Microbiol. 2011, 77, 2381-2391. [CrossRef] [PubMed]

10. Manyi-Loh, C.E.; Mamphweli, S.N.; Meyer, E.L.; Okoh, A.I.; Makaka, G.; Simon, M. Microbial Anaerobic Digestion (Bio-Digesters) as an Approach to the Decontamination of Animal Wastes in Pollution Control and the Generation of Renewable Energy. Int. J. Environ. Res. Public Health 2013, 10, 4390-4417. [CrossRef] [PubMed]

11. Franke-Whittle, I.H.; Walter, A.; Ebner, C.; Insam, H. Investigation into the effect of high concentrations of volatile fatty acids in anaerobic digestion on methanogenic communities. Waste Manag. 2014, 34, 2080-2089. [CrossRef] [PubMed]

12. Lin, J.; Zuo, J.; Gan, L.; Li, P.; Liu, F.; Wang, K.; Chen, L.; Gan, H. Effects of mixture ratio on anaerobic co-digestion with fruit and vegetable waste and food waste of China. J. Environ. Sci. 2011, 23, 1403-1408. [CrossRef]

13. Zhang, C.; Xiao, G.; Peng, L.; Su, H.; Tan, T. The anaerobic co-digestion of food waste and cattle manure. Bioresour. Technol. 2013, 129, 170-176. [CrossRef] [PubMed]

14. Fitamo, T.; Boldrin, A.; Boe, K.; Angelidaki, I.; Scheutz, C. Co-digestion of food and garden waste with mixed sludge from wastewater treatment in continuously stirred tank reactors. Bioresour. Technol. 2016, 206, 245-254. [CrossRef] [PubMed]

15. Mata-Alvarez, J.; Dosta, J.; Macé, S.; Astals, S. Codigestion of solid wastes: A review of its uses and perspectives including modeling. Crit. Rev. Biotechnol. 2011, 31, 99-111. [CrossRef] [PubMed]

16. Mao, C.; Feng, Y.; Wang, X.; Ren, G. Review on research achievements of biogas from anaerobic digestion. Renew. Sustain. Energy Rev. 2015, 45, 540-555. [CrossRef]

17. Esposito, G.; Frunzo, L.; Panico, A.; d'Antonio, G. Mathematical modelling of disintegration-limited co-digestion of OFMSW and sewage sludge. Water Sci. Technol. 2008, 58, 1513-1519. [CrossRef] [PubMed]

18. Wang, X.; Lu, X.; Li, F.; Yang, G. Effects of temperature and carbon-nitrogen $(\mathrm{C} / \mathrm{N})$ ratio on the performance of anaerobic co-digestion of dairy manure, chicken manure and rice straw: Focusing on ammonia inhibition. PLoS ONE 2014, 9, e97265. [CrossRef] [PubMed]

19. Zhu, S.; Wu, Y.; Yu, Z.; Zhang, X.; Li, H.; Gao, M. The effect of microwave irradiation on enzymatic hydrolysis of rice straw. Bioresour. Technol. 2006, 97, 1964-1968. [CrossRef] [PubMed]

20. Zabed, H.; Sahu, J.N.; Boyce, A.N.; Faruq, G. Fuel ethanol production from lignocellulosic biomass: An overview on feedstocks and technological approaches. Renew. Sustain. Energy Rev. 2016, 66, 751-774. [CrossRef]

21. Zheng, Y.; Zhao, J.; Xu, F.; Li, Y. Pretreatment of lignocellulosic biomass for enhanced biogas production. Prog. Energy Combust. Sci. 2014, 42, 35-53. [CrossRef]

22. Ravindran, R.; Jaiswal, A.K. Microbial Enzyme Production Using Lignocellulosic Food Industry Wastes as Feedstock: A Review. Bioengineering 2016, 3, 30. [CrossRef] [PubMed]

23. Bellasio, M.; Mattanovich, D.; Sauer, M.; Marx, H. Organic acids from lignocellulose: Candida lignohabitans as a new microbial cell factory. J. Ind. Microbiol. Biotechnol. 2015, 42, 681-691. [CrossRef] [PubMed]

24. Kumar, M.; Revathi, K.; Khanna, S. Biodegradation of cellulosic and lignocellulosic waste by Pseudoxanthomonas sp R-28. Carbohydr. Polym. 2015, 134 (Suppl. C), 761-766. [CrossRef] [PubMed]

25. The National Petroleum Council. Renewable Natural Gas for Transportation: An Overview of the Feedstock Capacity, Economics, and GHG Emission Reduction Benefits of RNG as a Low-Carbon Fuel; The National Petroleum Council: Washington, DC, USA, 2013; p. 44.

26. (EIA), U.S. Energy Information Administration. Monthly Energy Review: Energy Consumption by Sector; U.S. Energy Information Administration: Washington, DC, USA, 2013. 
27. Valentine, J.; Clifton-Brown, J.; Hastings, A.; Robson, P.; Allison, G.; Smith, P. Food vs. fuel: The use of land for lignocellulosic 'next generation' energy crops that minimize competition with primary food production. GCB Bioenergy 2012, 4, 1-19. [CrossRef]

28. Awais, M.; Alvarado-Morales, M.; Tsapekos, P.; Gulfraz, M.; Angelidaki, I. Methane Production and Kinetic Modeling for Co-digestion of Manure with Lignocellulosic Residues. Energy Fuels 2016, 30, 10516-10523. [CrossRef]

29. Kabir, M.M.; del Pilar Castillo, M.; Taherzadeh, M.J.; Sárvári Horváth, I. Effect of the $\mathrm{N}$-Methylmorpholine-N-Oxide (NMMO) Pretreatment on Anaerobic Digestion of Forest Residues. BioResources 2013, 8, 5409-5423. [CrossRef]

30. Achinas, S.; Achinas, V.; Euverink, G.J.W. A Technological Overview of Biogas Production from Biowaste. Engineering 2017, 3, 299-307. [CrossRef]

31. Brown, D.; Li, Y. Solid state anaerobic co-digestion of yard waste and food waste for biogas production. Bioresour. Technol. 2013, 127, 275-280. [CrossRef] [PubMed]

32. $\mathrm{Xu}, \mathrm{F}$; $\mathrm{Li}, \mathrm{Y}$. Solid-state co-digestion of expired dog food and corn stover for methane production. Bioresour. Technol. 2012, 118, 219-226. [CrossRef] [PubMed]

33. Jabeen, M.; Zeshan; Yousaf, S.; Haider, M.R.; Malik, R.N. High-solids anaerobic co-digestion of food waste and rice husk at different organic loading rates. Int. Biodeterior. Biodegr. 2015, 102, 149-153. [CrossRef]

34. Mulat, D.G.; Huerta, S.G.; Kalyani, D.; Horn, S.J. Enhancing methane production from lignocellulosic biomass by combined steam-explosion pretreatment and bioaugmentation with cellulolytic bacterium Caldicellulosiruptor bescii. Biotechnol. Biofuels 2018, 11, 19. [CrossRef] [PubMed]

35. Gerardi, M.H. The Microbiology of Anaerobic Digesters; John Wiley \& Sons, Inc.: Hoboken, NJ, USA, 2003; p. 177.

36. Lloret, E.; Pastor, L.; Pradas, P.; Pascual, J.A. Semi full-scale thermophilic anaerobic digestion (TAnD) for advanced treatment of sewage sludge: Stabilization process and pathogen reduction. Chem. Eng. J. 2013, 232, 42-50. [CrossRef]

37. Haider, M.R.; Zeshan; Yousaf, S.; Malik, R.N.; Visvanathan, C. Effect of mixing ratio of food waste and rice husk co-digestion and substrate to inoculum ratio on biogas production. Bioresour. Technol. 2015, 190, 451-457. [CrossRef] [PubMed]

38. Li, Y.; Zhang, R.; Liu, X.; Chen, C.; Xiao, X.; Feng, L.; He, Y.; Liu, G. Evaluating Methane Production from Anaerobic Mono- and Co-digestion of Kitchen Waste, Corn Stover, and Chicken Manure. Energy Fuels 2013, 27, 2085-2091. [CrossRef]

39. Li, L.; Yang, X.; Li, X.; Zheng, M.; Chen, J.; Zhang, Z. The Influence of Inoculum Sources on Anaerobic Biogasification of NaOH-treated Corn Stover. Energy Sources Part A 2010, 33, 138-144. [CrossRef]

40. Pommier, S.; Llamas, A.M.; Lefebvre, X. Analysis of the outcome of shredding pretreatment on the anaerobic biodegradability of paper and cardboard materials. Bioresour. Technol. 2010, 101, 463-468. [CrossRef] [PubMed]

41. Dhiman, S.S.; Shrestha, N.; David, A.; Basotra, N.; Johnson, G.R.; Chadha, B.S.; Gadhamshetty, V.; Sani, R.K. Producing methane, methanol and electricity from organic waste of fermentation reaction using novel microbes. Bioresour. Technol. 2018, 258, 270-278. [CrossRef] [PubMed]

42. Rice, E.W.; Bridgewater, L. Standard Methods for the Examination of Water and Wastewater; American Public Health Association: Washington, DC, USA, 2012.

43. Sluiter, A.; Hames, B.; Ruiz, R.; Scarlata, C.; Sluiter, J.; Templeton, D.; Crocker, D. Determination of Structural Carbohydrates and Lignin in Biomass; National Renewable Energy Laboratory: Golden, CO, USA, 2008.

44. Kaparaju, P.; Serrano, M.; Thomsen, A.B.; Kongjan, P.; Angelidaki, I. Bioethanol, biohydrogen and biogas production from wheat straw in a biorefinery concept. Bioresour. Technol. 2009, 100, 2562-2568. [CrossRef] [PubMed]

45. Dhar, H.; Kumar, P.; Kumar, S.; Mukherjee, S.; Vaidya, A.N. Effect of organic loading rate during anaerobic digestion of municipal solid waste. Bioresour. Technol. 2016, 217, 56-61. [CrossRef] [PubMed]

46. Bibra, M.; Kumar, S.; Wang, J.; Bhalla, A.; Salem, D.R.; Sani, R.K. Single pot bioconversion of prairie cordgrass into biohydrogen by thermophiles. Bioresour. Technol. 2018, 266, 232-241. [CrossRef] [PubMed]

47. Zhang, L.; Lee, Y.-W.; Jahng, D. Anaerobic co-digestion of food waste and piggery wastewater: Focusing on the role of trace elements. Bioresour. Technol. 2011, 102, 5048-5059. [CrossRef] [PubMed] 
48. Tanimu, I.; Mohd Ghazi, T.; Razif Harun, M.; Idris, A. Effect of Carbon to Nitrogen Ratio of Food Waste on Biogas Methane Production in a Batch Mesophilic Anaerobic Digester. Int. J. Innovation Technol. 2014, 5, 116-119.

49. Zhai, N.; Zhang, T.; Yin, D.; Yang, G.; Wang, X.; Ren, G.; Feng, Y. Effect of initial pH on anaerobic co-digestion of kitchen waste and cow manure. Waste Manag. 2015, 38, 126-131. [CrossRef] [PubMed]

50. Zhang, T.; Mao, C.; Zhai, N.; Wang, X.; Yang, G. Influence of initial pH on thermophilic anaerobic co-digestion of swine manure and maize stalk. Waste Manag. 2015, 35, 119-126. [CrossRef] [PubMed]

51. Zainab Ziad Ismail, A.R.T. Assessment of anaerobic co-digestion of agro wastes for biogas recovery: A bench scale application to date palm wastes. Int. J. Energy Environ. 2014, 5, 591-600.

52. Tong, X.; Smith, L.H.; McCarty, P.L. Methane fermentation of selected lignocellulosic materials. Biomass 1990, 21, 239-255. [CrossRef]

53. Ge, X.; Xu, F.; Li, Y. Solid-state anaerobic digestion of lignocellulosic biomass: Recent progress and perspectives. Bioresour. Technol. 2016, 205, 239-249. [CrossRef] [PubMed]

54. Shiralipour, A.; Smith, P.H. Conversion of biomass into methane gas. Biomass 1984, 6, 85-92. [CrossRef]

55. Schmidt, T.; Pröter, J.; Scholwin, F.; Nelles, M. Anaerobic digestion of grain stillage at high organic loading rates in three different reactor systems. Biomass Bioenergy 2013, 55, 285-290. [CrossRef]

56. Ferguson, R.M.W.; Coulon, F.; Villa, R. Organic loading rate: A promising microbial management tool in anaerobic digestion. Water Res. 2016, 100, 348-356. [CrossRef] [PubMed]

57. Cantrell, K.B.; Ducey, T.; Ro, K.S.; Hunt, P.G. Livestock waste-to-bioenergy generation opportunities. Bioresour. Technol. 2008, 99, 7941-7953. [CrossRef] [PubMed]

58. Esposito, G.; Frunzo, L.; Giordano, A.; Liotta, F.; Panico, A.; Pirozzi, F. Anaerobic co-digestion of organic wastes. Rev. Env. Sci. Biotechnol. 2012, 11, 325-341. [CrossRef]

59. Ahring, B.K. Methanogenesis in thermophilic biogas reactors. Antonie Leeuwenhoek 1995, 67, 91-102. [CrossRef] [PubMed]

60. Labatut, R.A.; Gooch, C.A. Monitoring of Anaerobic Digestion Process to Optimize Performance and Prevent System Failure; Department of Biological and Environmental Engineering, Cornell University: Ithaca, NY, USA, 2014.

(C) 2018 by the authors. Licensee MDPI, Basel, Switzerland. This article is an open access article distributed under the terms and conditions of the Creative Commons Attribution (CC BY) license (http:/ / creativecommons.org/licenses/by/4.0/). 